\title{
Effect of Different Prey Mites on the Biological Aspects and Life Table Parameters of the Cunaxid Mite, Cunaxa setirostris (Hermann) (Cunaxidae)
}

\author{
N.A. Omar* and O. M.O. Mohamed** \\ "Faculty of Technology \& Development, Zagazig University, Egypt \\ ${ }^{* *}$ Plant Protection Research Institute, A.R.C, Dokki, Egypt
}

\begin{abstract}
The effect of different preys on the biology, consumption rate and life table parameters of the predator, Cunaxa setirostris (Hermann) was investigated at $22 \pm 2^{\circ} \mathrm{C}$ and $75 \pm 5 \%$ R.H. C. setirostris was able to feed and complete its development on the three mite species Tetranychus urticae Kock, Tydeus californicus (Banks) and Eutetranychus africanus (Tucker). Predator female recorded the longest and the shortest life cycle, with larva and three nymphal stages within 31.5 and 23.9 days, when fed on E. africanus and T. californicus, respectively. The generation period ranged from 26.6 to 34.7 days when fed on T. californicus and E. orientalis, respectively. Its fecundity averaged of 52 and 18 eggs when fed on T. urticae and E. orientalis, respectively. The mean generation time (T) was (42.62, 38.62 and 48.54); the doubling time (DT) was (7.49, 7.42 and 4.31); the intrinsic rate of natural increase $\left(\mathrm{r}_{\mathrm{m}}\right)$ and finite rate of increase $(\lambda)$ were $(0.09,0.093$ and 0.16$)$ and $\left(1.07,1.08\right.$ and 1.04), respectively; while the net reproductive rate $\left(\mathrm{R}_{\mathrm{o}}\right)$ was $(24.35,17.55$ and 8.1); and gross reproductive rate (GRR) was (27.58, 22.01and 24.5) for C. siterostris fed on T. urticae, T. californicus and E. orientalis, respectively.
\end{abstract}

Key Words: Cunaxa setirostris, Biological aspects, Life table parameters.

\section{INTRODUCTION}

The family Cunaxidae was erected by Thor, (1902) as free living predatory mites that capture their prey with silk traps (Alberti and Ehrnsberger, 1977; Sergeyenko, 2009). Walter \& Kaplan, 1991 reported that cunaxid mites were recorded in both tropical and arctic regions, feeding on harmful mites, nematodes and small arthropods, although some species occasionally consume honeydew (Smiley, 1992; Gerson et al., 2003; Zhang, 2003; Bashir, et al., 2010).

Cunaxa is the largest genus of this family, comprising over 50 known species (Bashir, et al., 2011). Very little is known about the biology of cunaxids as the life cycle of only seven of nearly 260 described cunaxid species have been studied (Castro \& Moraes, 2010).

In Florida, Walter \& Proctor (1999) studied the feeding behavior of Cunaxidae, fed on nematodes and other soil arthropods. In India, Tagore and Putatunda (2003) reported that cunaxid mites were important predators in ornamental plants. Arbabi and Singh (2000) studied the biological aspects of Cunaxa setirostris fed on Tetranychus ludeni.

In Egypt, Soliman, et al. (1975) and Zaher, et al. (1975) studied the feeding habits and biology of the predaceous mite, Cunaxa capreolus Berlese on booklice (Psocoptera) and Eutetranychus orientalis (Klein).

Therefore, the present study aims to add highlight on the biological aspects and life table parameters of the cunaxid, $C$. setirostris fed on different preys under laboratory conditions.

\section{MATERIALS AND METHODS}

\section{Predatory mite rearing:}

Pure culture of $C$. setirostris was collected from mango leaves in Abou- Hammad, Sharqia governorate, Egypt. It was mass cultured on castor leaves, Ricinus communis infested with T. urticae as prey under laboratory conditions $22 \pm 2^{\circ} \mathrm{C}$ and $75 \pm 5 \%$ RH.

The predator was reared singly in small hemispherical plastic cells of $1 / 2$ inch in diameter and $1 / 4$ inch in depth. Mixture of plaster of Paris, clay and charcoal (5:4:1) was placed on the bottom at $3 \mathrm{~mm}$ depth and the top of each cell was covered with a small glass slide. Suitable moisture was maintained by adding 3 drops of water in every cell daily. The study was initiated with eggs of the predator ( $12 \mathrm{hs}$ old) obtained in the laboratory. Eggs were carefully transferred singly to experimental units. Fifteen replicates were used for each prey species. Prey mites Tetranychus urticae Koch, Tydius californicus (Banks) and Eutetranychus africanus (Tucker), were daily obtained from leaves of castor plants, mango and neem trees to feed $C$. setirostris. The units were kept at laboratory conditions, $22 \pm 2^{\circ} \mathrm{C}$ and $75 \pm 5$ R.H. and examined daily. Surplus known numbers of the preys were introduced to each predator and the devoured ones were daily replaced by others.

\section{Statistical analysis:}

The results were statistically analyzed by using the analysis of variance according to Sendecor and 
Cochron (1982) using the computer program SPSs (1997). The life table parameters: the intrinsic rate of natural increase $\left(r_{m}\right)$, net reproductive rate $\left(R_{o}\right)$, mean generation time $(\mathrm{T})$, doubling time (DT), gross reproduction rate (GRR) and finite rate of increase $(\lambda)$ were estimated according to Birch (1948) using the GW Basic computer program of Abou-Setta, et al. (1986).

\section{RESULTS AND DISCUSSION}

The cunaxid mite, $C$. setirostris successfully developed when reared on the three prey species. The female passes through egg, larva, three nymphal stages and adult. Each moving stage is preceded by a quiescent one.

\section{Effect of prey type on the developmental stages of the predator:}

Investigation showed that the prey type had a highly significant effect on the biological aspects of the predator, $C$. setirostris. The mean durations of the different stages of the female predator are shown in tables 1 and 2.

The incubation period was the longest stage. It averaged between 7.8 to 9.1 days when fed on nymphs of $T$. californicus and $T$. urticae, respectively.

Female larval, protonymphal, deutonymphal and tritonymphal stages averaged $(4.2,3.9,3.7 \& 4.1)$, $(6.6,5.2,4.8 \& 6.9)$ and $(6.1,4.8,3.8 \& 5.7)$ days when fed on nymphs of $T$. californicus, E. africanus and $T$. urticae, respectively.

The life cycle and the generation period were the longest (31.5\&34.7 days) when fed on E. africanus; and the shortest (23.9\&26.6 days) when fed on T. californicus, respectively (Table 1).

The maximum amount of feeding occurred during ovipositional period (34 days) with an average fecundity of $73 \pm 2.11$ eggs/ female when fed on $T$. urticae, with an average prey consumption of $178 \pm 6.25$ nymphs. While the minimum amount of feeding occurred during ovipositional period (47 days) with an average fecundity of $18 \pm 1.15$ eggs/ female when fed on E. africanus with an average prey consumption of $79 \pm 4.16$ nymphs. So, the feeding capacity and fecundity decreased as the oviposition period increased with a highly significant effect (Table 2).

The fecundity/female/day was $(1.53,1.01$ and 0.38 eggs) when feeding on T. urticae, $T$. californicus and E. africanus, respectively.

\section{Life table parameters:}

The calculated life table parameters were constructed using the survival data of specific age class and (LX) and the female offspring produced per female in each age class $(\mathrm{mx})$. The net reproductive rate $\left(R_{o}\right)$, the mean generation time $(T)$, the intrinsic rate of increase $\left(r_{m}\right)$, the finite rate of increase $(\lambda)$, Doubling time (DT) and Gross reproduction rate (GRR) were estimated (Table 3).

The population of the predator $C$. setirostris had the capacity to double (DT) every $(7.49,7.42$ and 4.31 times) within a single generation when fed on $T$. urticae, T. californicus and E. africanus, respectively. The intrinsic rate of increase $\left(\mathrm{r}_{\mathrm{m}}\right)$ was $0.09,0.093$ and 0.16 individual/day, while the finite rate of increase $(\lambda)$ was $(1.07,1.08$ and 1.04 female daughters/female/day) for $T$. urticae, $T$. californicus and E. africanus, respectively. On the other hand, it could be observed that the net reproduction rate $\left(R_{\mathrm{o}}\right)$ varied being $(24.35,17.55$ and 8.1 times) during the mean generation time (T) 42.62, 38.62 and 48.54 days for $T$. urticae, T. californicus and E. africanus, respectively. Gross reproductive rate (GRR) was $(27.58,22.01$ and 24.5) times/female/day.

C. setirostris is able to feed and develop on the three prey mite species. The female of this species pass through egg, larva, three nymphal stages and adult. Similar findings were reported for other cunaxid species revealed that $C$. capreolus Berlese successfully developed on diets of booklice (Psocoptera) and the citrus brown mite, Eutetranychus orientalis (KLEIN); Soliman, et al. (1975); Zaher, et al. (1975) and Arbabi\&Singh (2000).

The incubation period was the longest immature stage, lasting 9.1, 7.8 and 8.1 day when fed on nymphs of $T$. urticae, T. californicus and $E$. africanus, respectively. These results were similar to those of Castro (2008) and Castro\&Moraes (2010).

The female life cycle and the generation time were longest when feeding on E. africanus, while the shortest on $T$. californicus. This coincides with the results obtained by Zaher, et al. (1975) who reared $C$. capreolus on booklice (Psocoptera) and E. orientalis at $30^{\circ} \mathrm{C}$, the predator completed its generation in about 4 weeks; Arbabi and Singh (2000) stated that C. setirostris female completed its life cycle on $T$. ludeni within 27.51 days, with one larval stage followed by three nymphal stages.

On the other hand, Zhang (2003) reported that the generation time of Coleoscirus simplex (Ewing) lasted two weeks, with the daily rate of deposited eggs $4.4 \mathrm{egg} /$ female. 
Table (1): Mean developmental times in days of $C$. setirostris fed on different preys at $22 \pm 2^{\circ} \mathrm{C}$ and $70 \pm 5 \%$ R.H.

\begin{tabular}{cccccccc}
\hline & Incubation period & Larva & Protonymph & Deutonymph & Tritonymph & Life cycle & Generation \\
\hline T. urticae & $9.1 \pm 0.82^{\mathrm{a}}$ & $6.1 \pm 0.74^{\mathrm{a}}$ & $4.8 \pm 0.79^{\mathrm{a}}$ & $3.8 \pm 0.79^{\mathrm{b}}$ & $5.7 \pm 0.67^{\mathrm{b}}$ & $29.4 \pm 1.71^{\mathrm{b}}$ & $31.3 \pm 1.67 \mathrm{~b}$ \\
\hline T. californicus & $7.8 \pm 0.63^{\mathrm{b}}$ & $4.2 \pm 0.79^{\mathrm{b}}$ & $3.9 \pm 0.88^{\mathrm{b}}$ & $3.7 \pm 0.86^{\mathrm{b}}$ & $4.1 \pm 0.74^{\mathrm{c}}$ & $23.9 \pm 2.18^{\mathrm{c}}$ & $26.6 \pm 2.46^{\mathrm{c}}$ \\
\hline E. africanus & $8.1 \pm 0.81^{\mathrm{b}}$ & $6.6 \pm 0.69^{\mathrm{a}}$ & $5.2 \pm 0.92^{\mathrm{a}}$ & $4.8 \pm 0.79^{\mathrm{a}}$ & $6.9 \pm 0.73^{\mathrm{a}}$ & $31.5 \pm 1.9^{\mathrm{a}}$ & $34.7 \pm 2.11^{\mathrm{a}}$ \\
\hline Sig. & $* *$ & $* *$ & $* *$ & $*$ & $* * *$ & $* * *$ & $* * *$ \\
\hline
\end{tabular}

Means with different superscripts in the same row differ significantly $(\mathrm{P}<0.05)$.

Table (2): Mean durations of adult stage and fecundity of $C$. setirostris fed on different preys at $22 \pm 2^{\circ} \mathrm{C}$ and $70 \pm 5 \%$ R.H.

\begin{tabular}{lccccccc}
\hline & Preoviposition & oviposition & postoviposition & Adult & Fecundity & eggs/female/day & consumption \\
\cline { 2 - 7 } & & & longevity & oviposition period \\
\hline T. urticae & $1.9 \pm 0.32^{\mathrm{b}}$ & $34 \pm 0.82^{\mathrm{c}}$ & $4.4 \pm 0.52^{\mathrm{b}}$ & $40.3 \pm 0.95^{\mathrm{c}}$ & $73 \pm 2.11^{\mathrm{a}}$ & $1.53 \pm 0.08^{\mathrm{a}}$ & $178 \pm 6.25^{\mathrm{a}}$ \\
\hline T. californicus & $2.7 \pm 0.67^{\mathrm{a}}$ & $39 \pm 2.45^{\mathrm{b}}$ & $5.1 \pm 1.1^{\mathrm{b}}$ & $46.8 \pm 2.86^{\mathrm{b}}$ & $39 \pm 2.00^{\mathrm{b}}$ & $1.01 \pm 0.08^{\mathrm{b}}$ & $83 \pm 7.69^{\mathrm{b}}$ \\
\hline E. africanus & $3.2 \pm 0.79^{\mathrm{a}}$ & $47 \pm 1.63^{\mathrm{a}}$ & $8.2 \pm 0.63^{\mathrm{a}}$ & $58.4 \pm 2.22^{\mathrm{a}}$ & $18 \pm 1.15^{\mathrm{c}}$ & $0.38 \pm 0.03^{\mathrm{c}}$ & $79 \pm 4.16^{\mathrm{b}}$ \\
\hline Sig. & $*$ & $* * *$ & $*$ & $* * *$ & $* * *$ & $* * *$ & $* * *$ \\
\hline
\end{tabular}

Means with different superscripts in the same row differ significantly $(\mathrm{P}<0.05)$.

Table (3): Life table parameters of $C$. setirostris fed on different preys at $22 \pm 2^{\circ} \mathrm{C}$ and $70 \pm 5 \%$ R.H.

\begin{tabular}{lccc}
\hline \multicolumn{1}{c}{ Parameters } & T. urticae & T. californicus & E. africanus \\
\hline Mean generation time $(\mathrm{T})^{\mathrm{a}}$ & 42.62 & 38.62 & 48.54 \\
\hline${\text { Doubling time }(\mathrm{DT}){ }^{\mathrm{a}}}^{\mathrm{N}}$ & 07.49 & 7.42 & 4.31 \\
\hline${\text { Net reproductive rate }\left(\mathrm{R}_{\mathrm{o}}\right)^{\mathrm{b}}}^{\text {Intrinsic rate of increase }\left(\mathrm{r}_{\mathrm{m}}\right)^{\mathrm{c}}}$ & 24.35 & 17.55 & 8.1 \\
\hline Finite rate of increase $\left(\lambda-\mathrm{e}^{\mathrm{rm}}\right)$ & 00.09 & 0.093 & 0.16 \\
\hline Gross reproduction rate $(\mathrm{GRR})$ & 01.07 & 1.08 & 1.04 \\
\hline
\end{tabular}

${ }^{\mathrm{a}}$ Days ${ }^{\mathrm{b}}$ Per generation ${ }^{\mathrm{c}}$ Individuals/female/ day

Maximum prey consumption during oviposition period for C. setirostris was 178 nymphs with 73 eggs/female when fed on T. urticae; while the minimum was 79 nymphs with 18 eggs/female when fed on E. africanus. Similar findings were reported by Soliman, et al. (1975); Taha, et al. (1988); Castro and Moraes, (2010).

On the other hand, Arbabi and Singh (2000) found that the maximum amount of feeding occurred during oviposition period for the predator, C. setirostris fed on T. ludeni.

The intrinsic rate of increase $\left(r_{m}\right)$ was low. It ranged between 0.09 to 0.16 individual/day suggesting that those prey species may not be suitable for the predator. Similar results were obtained by Castro and Moraes (2010); Castro (2008) suggesting that life table parameters of Estudos taxonômicos had low biotic potential on Tenuipapus heveae Baker. He reported that the factors that could determin the estimated low biotic potential were the long developmental time from egg to adult (about 33 days), mainly because of the long duration of the egg stage (about 17 days), the low viability of the immature phase (10\%) and the low fecundity (12 eggs per female).

Therefore, it could be concluded that the predacious mite, $C$. setirostris could be considered useful agents against phytophagous mites.

\section{REFERENCES}

Abou-Setta, M. M.; Sorrell, R.W. and Childers, C.C.1986. Life 48 a BASIC computer program to calculate life table parameters for an insect or mite species. Fla. Ent., 69: 690 - 697.

Alberti, G. and Ehrnsberger, R.1977. Raster electron en mikroskopische untersuchungen zum Spinnvermögen der Bdelliden und Cunaxiden (Acari, Prostigmata).Acarologia, 19, 55-61

Arbabi, M. and Singh, J. 2000. Studies on biological aspects of predaceous mite Cunaxa setirostris on Tetranychus ludeni at laboratory condition in Varanasi. India Journal of Agriculture and Rural Development, 2 (1):13-23.

Bashir, M. H.; Muhammad, A.; Ashfaq, M.; Shamshad, A. and Shaukat, A. 2010. Two New Species of the Genus Cunaxa (Acari: Cunaxidae) 
from District Nankana. Pakistan J. Zool., 42(3): 217-222.

Bashir, M. H.; Muhammad, A.; Ashfaq, M.; Abo Bakar, M. R. and Karman, A. 2011. Record of one new species of the genus Cunaxa (Acari: Cunaxidae) from Rice Husk. Pakistan J. Zool., 43(1): 37-40.

Castro, T. M. M. G. 2008. Estudos Taxonômicos E Biológicos de Cunaxidae (Acari: Prostigmata) do Brasil. Ph. D. dissertation Jaboticabal-São Paulo-Brasil, pp 99.

Castro, T. M. M. G. and Moraes, G. J. 2010. Life cycle and behavior of the predacious mite Cunaxatricha tarsospinosa (Acari: Prostigmata: Cunaxidae). Exp. Appl. Acarol., 50: 133-139.

Gerson, U.; Smiley, R. L. and Ochoa, R. 2003. Mites (Acari) for pest control. Back well Science Ltd, Oxford.

Sergeyenko, A. L. 2009. New mite species of the genus Cunaxa (Acari: Prostigmata: Cunaxidae) from the Crimea, Ukraine. Zootaxa, 2161: 1-19.

Smiley, R. L. 1992. The predatory mite family Cunaxidae (Acari) of the world with a new classification. Indira Publishing House, Michigan, $356 \mathrm{pp}$.

Snedecor, G.W. and Cochran, G.W.1982. Statistical Methods. Iowa State Uinv., Press, 7 Edition Ames, USA.

Soliman, Z. R.; Zaherand, M. A. and El-Bishlawy, S. M. 1975. Studies on the biology of the predaceous mite, Cunaxa capreolus Berl. (Acarina: Prostigmata: Cunaxidae).Anzeiger für Schädlingskunde, Pflanzenschutz, Umweltschutz, 48(8):124-126.

SPSs. 1997. SPSs users Guide Statistics. Version 8.
Copyright SPSs Inc. USA.

Tagore, A. and Putatunda, B. N.2003. Mites associated with some ornamental plants at Hisar, Haryana. Pest Management and Economic Zoology, 11(1): 37-44.

Taha, H. A.; El-Naggar, M. E. E.; Abou El-Naga, M. M. and Soliman, S.M.1988. Effect of different prey species on the development and fecundity of the predaceous mite, Neocunaxoides andrei Baker \& Hoff. (Acari: Cunaxidae). Agric. Res. Rev., 66 (1):129-135.

Thor, S.1902. On the systematic representation of the Acarinen familien Bdellidae Koch, 1842, Grube, 1859, Eupodidae Koch, 1842 and Cunaxidae Sig Thor, 1902. Verhandlungen der ZoologischBotanischen Gesellschaft in Wien, 52: 159-165.

Von Heyden, C.1826. Versuch einer systematischen eintheiling der Acariden. Isis of Oken, 18(6), 608613.

Walter, D.E. and Proctor, H.C.1999. Mites: ecology, evolution and behaviour. University of New South Wales Press and CABI Publishing Wallingford.

Walter, D.E. and Kaplan, D.T.1991. Observations on Coleoscirus simplex (Acarina: Prostigmata), a predatory mite that colonizes greenhouse cultures of root knot nematode (Meloidogyne spp.), and a review of the feeding behaviour in the Cunaxidae. Exp. and Appl. Acarol., 12: 47-59.

Zaher, M. A.; Soliman, Z. R. and El-Bishlawy, S. M.1975. Feeding habits of the predaceous mite, Cunaxa capreolus (Acarina: Cunaxidae). Entomophaga, 20(2): 209-212.

Zhang, Z.Q.2003. Mites of greenhouses: identification, biology and control. $\mathrm{CAB}$ International, Wallingford, UK, 244 pp. 